\title{
PENYUSUNAN BAHAN AJAR BERBASIS VLOG DALAM MENINGKATKAN KETERAMPILAN KOMUNIKASI MAHASISWA PGSD IKIP SILIWANGI
}

\author{
Rony Mugara ${ }^{1}$, Galih Dani Septiyan Rahayu ${ }^{2}$, Hana Sakura Putu Arga ${ }^{3}$ \\ 1, 2, 3, 4, ${ }^{5}$ Pendidikan Guru Sekolah Dasar, IKIP Siliwangi \\ ${ }^{1}$ ronnymugara@ikipsiliwangi.ac.id \\ galih040990@ikipsiliwangi.ac.id \\ 3. hana-sakura@ikipsiliwangi.ac.id
}

\begin{abstract}
This research is motivated by the importance of increasing the creativity of prospective educators in making innovative instructional media based on online technology as a challenge in the revolutionary era 4.0 and student communication skills that have not been maximized. Therefore, research on the preparation of vlog-based teaching materials is carried out in an effort to improve student communication skills. The method used in this study was quasi-experimental with a non-equivalent pretest posttest control group design. The population in this study were all PGSD students in the $4^{\text {th }}$ of the 2018-2019 academic year with the selected sample namely regular class A1 students as the experimental class and regular A2 class students as the control class. The instrument used in this study is the observation sheet according to communication skills indicators. The results showed an increase in communication skills in PGSD students by making compilation of vlog-based teaching materials.
\end{abstract}

Keywords : vlog, communication skills

Abstrak : Penelitian ini dilatarbelakangi oleh pentingnya peningkatan kreativitas mahasiswa calon pendidik dalam membuat media ajar yang inovatif berbasis teknologi online sebagai tantangan di era revolusi 4.0 dan belum maksimalnya keterampilan komunikasi mahasiswa. Oleh karena itu, dilaksankan penelitian penyusunan bahan ajar berbasis vlog dalam upaya meningkatkan keterapilan komunikasi mahasiswa. Metode yang digunakan dalam penelitian ini adalah kuasi eksperimen dengan desain non-equivalent pretest postest control group desain. Populasi pada penelitian ini adalah seluruh mahasiswa PGSD semester 4 tahun ajaran 2018-2019 dengan sampel yang dipilih yaitu mahasiswa reguler kelas A1 sebagai kelas eksperimen dan mahasiswa reguler kelas A2 sebagai kelas kontrol. Instrumen yang digunkan pada penelitian ini adalah lembar observasi sesuai indikator keterampilan komunikas. Hasil menunjukan adanya peningkatan keterampilan komunikasi pada mahasiswa PGSD IKIP Siliwangi dengan membuat penyusunan bahan ajar berbasis vlog.

Kata Kunci: vlog, Keterampilan komunikasi

\section{PENDAHULUAN}

Penelitian ini dilatarbelakangi oleh pentingnya kemampuan mahasiswa calon pendidik SD untuk memiliki keterampilan komunikasi dengan memanfaatkan media teknologi yang semakin hari semakin berekembang. Komunikasi merupakan alat untuk membina hubungan sebagai implementasi dari kodrat manusia sebagai makhluk sosial. Marfuah (2017) menjelaskan bahwa Komunikasi merupakan proses individu dalam hubungan, kelompok, organisasi, dan masyarakat membuat dan menggunakan informasi untuk berhubungan satu sama lain dengan lingkungan. Komunikasi merupakan sarana menampilkan pesan, mengekspresikan diri, serta mempengaruhi orang lain. Oleh karena itu, perlulah pendidik memiliki keterampilan komunikasi yang baik agar mampu menciptakan kegiatan pembelajaran menjadi lebih efektif dalam membangun komunikasi antara guru dengan peserta didik, ataupun diantara sesama peserta didik sehingga tujuan pembelajaran dapat tercapai.

Dalam upaya mengatasi permasalahan-permasalahan tersebut perlu adanya tindakan lanjutan yang dilakukan untuk meningkatkan keterampilan komunikasi pada mahasiswa PGSD IKIP Siliwangi mengingat ketika melihat dilapangan para mahasiswa cenderung hanya menggunakan teknologi untuk kepentingan pribadi saja dalam memanfaatkan media sosial dan ketika dalam proses pembelajaran mahasiswa cenderung kaku dalam berkomunikasi, hal ini terlihat ketika mahasiswa melakukan presentasi dimana mahasiswa yang menyampikan materi terlihat kaku dan penyampaian informasi tidak bisa memahamkan audience sehingga 
pembelajaran menjadi tidak kondusif terlebih lagi dalam kegiatan praktek mengajar mahasiswa cenderung jarang menyusun bahan ajar yang berbasis teknologi. Dari beberapa pernyataan tersebut rumusan masalah pada penelitian ini yaitu 1) apakah terdapat peningkatan keterampilan komunikasi mahasisswa PGSD IKIPSiliwangi melalui penyusunan ajar berbasis vlog?; 2) apakah terdapat peningkatan keterampilan komunikasi mahasiswa PGSD IKIP Siliwangi melalui pembelajaran konvensional (presentasi dan demonstrasi)?; 3) apakah terdapat peningkatan keterampilan komunikasi mahasiswa PGSD IKIP Siliwangi antara kelas eksperimen dan kelas kontrol?. Tujuan penelitian ini adalah 1) untuk mengetahui apakah terdapat peningkatan keterampilan komunikasi mahasisswa PGSD IKIPSiliwangi melalui penyusunan ajar berbasis vlog; 2) untuk mengetahui apakah terdapat peningkatan keterampilan komunikasi mahasiswa PGSD IKIP Siliwangi melalui pembelajaran konvensional (presentasi dan demonstrasi); 3) untuk mengetahui apakah terdapat perbedaan peningkatan keterampilan komunikasi mahasiswa PGSD IKIP Siliwangi antara kelas eksperimen dan kelas kontrol.

Upaya yang dianggap mampu mengatasi permasalahan-permasalahan tersebut yaitu menciptakan pembelajaran yang efektif, bermakna, menantang, dan menarik. Dalam mewujudkan pembelajaran tersebut salah satunya dapat memanfaatkan teknologi keterbaharuan dalam kegiatan pembelajaran seperti penyusunan bahan ajar berbasis vlog. Hal ini sejalan dengan pendapat Priana (2017) yang menjelaskan bahwa dampak perkembangan teknologi berimbas pada proses pembelajaran dimana para pendidik harus mampu melakukan berbagai inovasi dan kreatifitas agar proses pembelajaran selalu relevan dengan perkembangan yang ada. Inovasi dan kreatifitas yang dapat dilakukan pendidik salah satunya dengan penggunaan teknologi informasi sebagai media pembelajaran. Pemanfaatan bahan ajar vlog dalam proses pembelajaran mampu memberikan keterampilan komunikasi pada mahasiswa agar dapat beradaptasi dan berkembang di era revolusi 4.0. Seseorang yang memiliki keterampilan komunikasi baik akan mampu berbicara dan berbaur dengan setiap orang pada setiap golongan begitupun dengan peserta didik. Dari pemaparan tersebut maka dilaksanakan penelitian dengan judul penyusuanan bahan ajar berbasis vlog dalam menigkatkan keterampilan komuniiasi mahasiswa PGSD IKIP Siliwangi.

\section{Bahan Ajar Berbasis Aplikasi Vlog}

Bahan ajar merupakan salah satu bagian dari sumber ajar yang dapt diartikan sesuatu yang mengandung pesan pembelajaran, baik yang bersifat khusus maupun bersifat umum yang dapat dimanfaatkan untuk kepentingan belajar Mulyasa (2006). Arsanti (2018) menjelaskan bahawa dalam memilih, menentukan, dan mengembangkan suatu bahan ajar atau materi ajar harus memperhatikan kriteria atau karakteristik materi ajar. Dalam hal ini pendidik harus memperhatikan empat kriteria yang harus terpenuhi dalam materi ajar, yaitu (1) cakupan isi, (2) penyajian, (3) keterbacaan, dan (4) kegrafikaan. Keempat kriteria tersebut harus terpenuhi agar materi yang dipilih atau dikembangkan dapat dikatakan baik atau layak digunakan sebagai sumber informasi dalam pembelajaran. Melihat pendapat tersebut dapat dipahami bahwa untuk memberikan sumber informasi dalam pembelajaran perlulah penyusunan bahan ajar yang kreatif untuk memenuhi kriteria pembelajaran yang bisa dipahami dan tidak membosankan peserta didik salah satunya adalah bahan ajar yang mengikuti perkembangan teknologi saat ini yaitu internet karena kemajuan teknologi khususnya internet telah sejalan dengan tuntutan generasi internet ini sehingga pengintegrasian nya akan sesuai dengan cara belajar sehingga proses belajar dan hasil pembelajaran akan optimal.

David, dkk (2017) berpendapat bahwa vlog atau video blogging merupakan video berisi mengenai opini, cerita atau kegiatan harian yang biasanya dibuat tertulis pada blog. Video blog atau biasa disingkat $v \log$ merupakan salah satu fasilitas media bebrbasis internet yang berfungsi memberikan pesan untuk disampaikan lebih menarik. Bahan ajar bebasis vlog pada penelitian ini yaitu bahan ajar yang dibuat selama proses pembelajaran dengan memanfaatkan vlog yang dibuat oleh mahasiswa dengan bimbingan dari dosen. Selain membuat video yang menarik subjek penelitian juga menuliskan hal-hal yang ada pada video dan dilengkapi dengan lembar kerja siswa (LKS). Dengan kegiatan pembelajaran seperti ini mahasiswa diharapkan bisa lebih antusias dalam belajar dan lebih kreatif dalam membuat bahan ajar.

\section{Keterampilan Komunikasi}

Chatab (2007) menjelaskan bahwa keterampilan komunikasi merupakan kemampuan mengadakan hubungan lewat saluran komunikasi manusia atau media, sehingga pesan atau informasinya dapat dipahami dengan baik. Indikator keterampilan komunikasi adalah sebagai berikut: 
1. Keterampilan komunikasi verbal yang meliputi: kemampuan seseorang dalam menyampaikan ide atau pendapat, keterampilan dalam berdiskusi, keterampilan dalam melakukan presentasi, pembicaraan yang jelas dan bisa dimengerti oleh lawan bicara serta keterampilan dalam mengajukan pertanyaan.

2. Keterampilan komunikasi nonverbal yang meliputi: ekspresi wajah yang ramah saat berbicara dengan orang lain, gerakan tubuh seperti tangan yang sesuai dengan perkataan yang diucapkan, nada bicara yang menarik perhatian lawan bicara.

\section{Mata Kuliah Magang IPS SD}

Mata kuliah Magang IPS SD merupakan kegiatan pembelajaran yang mengkaji tentang IPS di SD sambil melakukan (learning by doing) untuk memberikan pengalaman dalam membentuk kepribadian sebagai pengajar, mengembangkan kecakapan pedagogis, memantapkan kompetensi dalam bidang ilmu IPS di SD serta mengembangkan kreativitas mahasiswa dalam membuat prangkat pembelajaran.

Ruang lingkup mata kuliah magang IPS SD adalah sebagai berikut:

1. Pemahaman materi pembelajaran IPS SD.

2. Penguatan jati diri untuk membentuk kepribadian sebagai pendidik.

3. Mengembangkan kompetensi pedagogik.

4. Mengembangkan kreativitas mahasiswa dalam membuat bahan ajar, media ajar daninstrumen pembelajaran IPS SD.

5. Memberikan pembelajaran dengan pengalam langsung belajar secara mandiri untuklangsung terjun kelapangan.

\section{METODE}

Metode yang digunakan pada penelitian ini adalah metode kuasi eksperimen dengan desain penelitian nonequivalent pretest postest control group desain. Desain penelitian non-equivalent pretest postest control group desain, menurut Septiyan (2017) non-equivalent pretest postest control group desain yang dapat digambarkan sebagai berikut.

Tabel . Non-equivalent pretest postest control group desain

\begin{tabular}{cccc} 
Kelas & Pretest & Treatment & Postest \\
\hline Eksperimen & $\mathrm{T}_{0}$ & $\mathrm{X}_{1}$ & $\mathrm{~T}_{1}$ \\
\hline Kontrol & $\mathrm{T}_{0}$ & $\mathrm{X}_{2}$ & $\mathrm{~T}_{1}$
\end{tabular}

Keterangan: $\quad \mathrm{T}_{0}$ : Pretest yang dilaksankan di kelas eksperimen dan kontrol

$\mathrm{T}_{0:}$ Posttest yang dilaksankan di kelas eksperimen dan kontrol

$\mathrm{X}_{1}$ : Perlakuan di kelas eksperimen

$\mathrm{X}_{2}$ : Perlakuan di kelas kontrol

$\mathrm{T}_{1}$ : Pretest yang dilaksankan di kelas eksperimen dan kontrol

$\mathrm{T}_{1:}$ Posttest yang dilaksankan di kelas eksperimen dan kontrol

Populasi pada penelitian ini adalah seluruh mahasiswa PGSD semester 4 kelas regular dan kelas non reguler dengan jumlah 392 mahasiswa. Pengambilan sampel tidak dilaksankan dengan acak dan sampel pada peneitian ini yaitu mahasiswa PGSD A1 semester 4 dengan jumlah 41 dan kelas A2 dengan jumlah 39 sehingga jumlah sampel seuruhnya adalah 80 mahasiswa. Lokasi pada penelitian ini yaitu Institut Keguruan dan Ilmu Pendidikan (IKIP) Siliwangi yang beralamat di Jl. Terusan Jend. Sudirman, Baros, Cimahi Tengah, Kota Cimahi. IKIP Siliwangi merupakan salah satu perguruan tinggi swasta yang berada di bawah nauangan LLDIKTI wilayah IV. Instrumen yang digunakan dalam penelitian ini yaitu instrumen keterampilan komunikasi sesuai dengan indikator-indikator keterampilan komunikasi, setelah itu instrumen divalidasi ke ahli dan dilakukan validasi ke lapangan agar instrumen benar-benar teruji validitasnya. Kemudian instrumen tersebut digunakan pada tahap pretest dan posttest yang kemudian di olah dan dianalisis menggunkan bantuan aplikasi SPPs 25.

Prosedur penelitian pada penelitian ini terdiri dai empat tahapan yaitu tahap persiapan, tahap pelaksanaan, tahap penyelesaian, dan tahap publikasi. Tahapan persiapan kegiatan yang dilakukan adalah menganalisis hasil-hasil penelitian yang sebelumnya sudah dilakukan mengenai keterampilan komunikasi, menganalisis perkembangan mahasiswa dalam penyusunan bahan ajar, menyususn bahan ajar berbasis vlog, menyusun instrumen, validasi, dan uji coba instrumen. Pada tahap pelaksanaan, kegiatan yang dilaksanakan adalah pelaksanaan pretest, melaksanakan pembelajaran di kelas eksperimen menggunakan bahan ajar berbasis 
vlog dan di kelas kontrol menggunakan pembelajaran konvensional, serta pelaksanaan posttest. Pada tahap akhir penelitian kegiatan yang dilaksanakan yaitu mengumpulkan data hasil penelitian, mengolah dan menganalisis hasil penelitian, dan penyusunan laporan penelitian. Pada tahap publikasi penelitian kegiatan yang dilaksankan yaitu mempublikasi hasil penelitian.

\section{HASIL DAN PEMBAHASAN}

Hasil

Hasil penelitian yang didapatkan untuk menjawab rumusan masalah pertama mengenai apakah terdapat peningkatan keterampilan komunikasi mahasiswa PGSD IKIP Siliwangi kelas A1 melalui penyusunan bahan ajar berbasis vlog. Hasil penelitian yang didapatkan adalah peningkatan keterampilan komunikasi mahasiswa yang signifikan dengan kegiatan pembelajaran penyusunan bahan ajar berbasis vlog. Hasil penelitian diperoleh melalui pengolahan dan analisis data menggunakan aplikasi SPSS 25. Adapun hasil pengolahan datanya sebagai berikut:

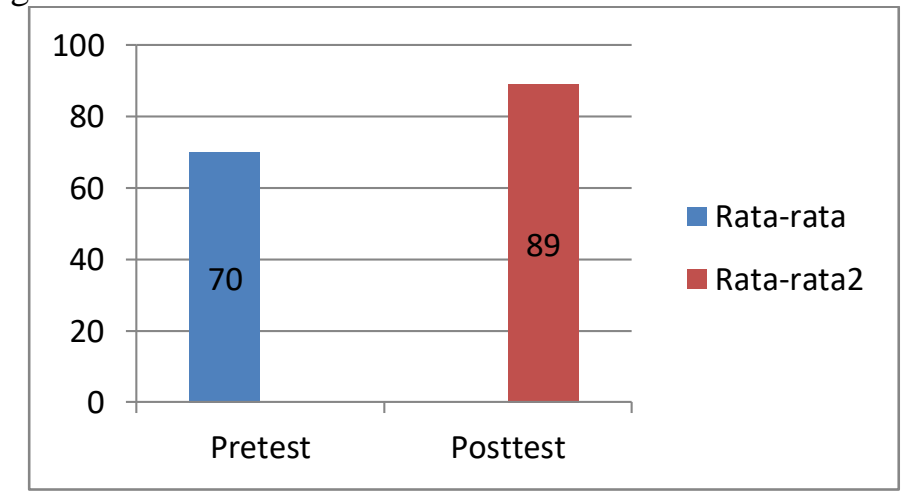

Grafik 1. Rata-rata nilai keterampilan komunikasi kelas eksperimen

Hasil pengolahan menggunkan statistik uji t diperoleh data sig. (2-tailed) yaitu 0,000 dibagi dua karena hipotesisnya satu arah maka diperoleh sig. (one-tailed) yaitu $0,000<0,05$ maka dapat diartikan terdapat peningkatan keterampilan komunikasi mahasiswa A1 yang signifikan dengan menggunakan bahan ajar. Adapun hasil pengolahan uji statistinya dapat dilihat pada tabel 1.

Tabel 1. Hasil uji t keterampilan komunikasi kelas eksperimen

\begin{tabular}{lccc}
$\begin{array}{c}\text { Uji t kelas } \\
\text { Eksperimen }\end{array}$ & Sig.(2-tailed) & Signifikansi & Keterangan \\
\hline $\begin{array}{l}\text { Pretest } \\
\text { posttest }\end{array}$ & $0,000: 2=\mathbf{0 , 0 0 0}$ & 0,05 & $\begin{array}{c}\text { Terdapat } \\
\text { Peningkatan }\end{array}$ \\
\hline
\end{tabular}

Hasil penelitian yang sesuai dengan rumusan masalah kedua apakah terdapat terdapat peningkatan keterampilan komunikasi mahasiswa kelas A2 PGSD IKIP Siliwangi melalui pembelajaran konvensional (presentasi dan demonstrasi). Hasil penelitian yang didapatkan adalah adanya peningkatan keterampilan komunikasi pada siswa yang menggunakan pembelajaran konvensional. Hasil penelitian ini diperoleh melalui pengolahan dan analisis data menggunakan aplikasi SPSS 25. Adapun hasil pengolahannya adalah sebagai berikut.

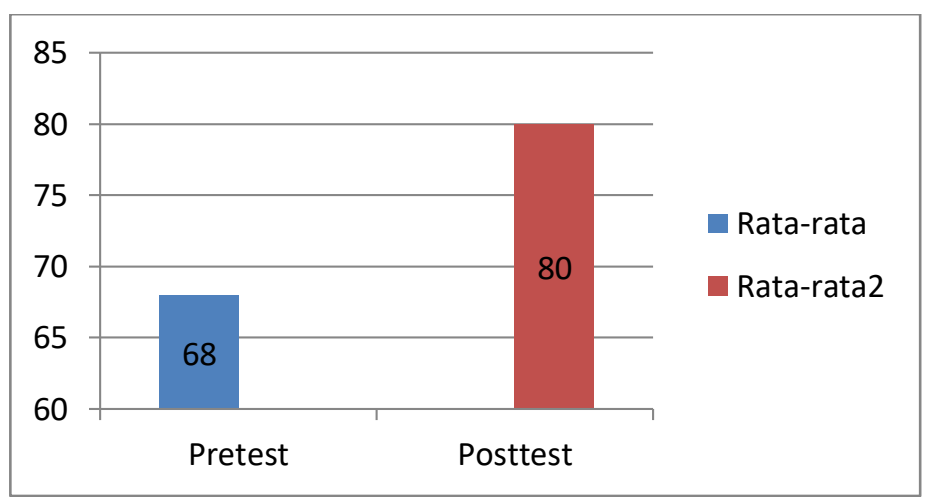

Grafik 2. Rata-rata nilai keterampilan komunikasi kelas kontrol 
Hasil pengolahan menggunkan statistik uji t diperoleh data sig. (2-tailed) yaitu 0,02 dibagi dua karena hipotesisnya satu arah maka diperoleh sig. (one-tailed) yaitu $0,01<0,05$ maka dapat diartikan terdapat peningkatan keterampilan komunikasi yang signifikan pada mahasiswa A2 PGSD IKIP Siliwangi dengan menggunakan pembelajaran konvensional. Adapun hasil pengolahannya dapat dilihat pada tabel 3.

Tabel 3. Hasil uji t keterampilan komunikasi kelas kontrol

\begin{tabular}{lccc}
$\begin{array}{c}\text { Uji t kelas } \\
\text { Kontrol }\end{array}$ & Sig.(2-tailed) & Signifikansi & Keterangan \\
\cline { 1 - 2 } & $0,020: 2=\mathbf{0 , 0 1 0}$ & 0,05 & $\begin{array}{c}\text { Terdapat } \\
\text { Peningkatan }\end{array}$
\end{tabular}

Hasil penelitian yang menjawab rumusan masalah ketiga tentang apakah terdapat perbedaan peningkatan keterampilan komunikasi mahasiswa antara di kelas eksperimen dengan di kelas kontrol. Hasil yang diperoleh melalui pengolahan dan analisis data yaitu keterampilan komunikasi mahasiswa di kelas eksperimen mengalami peningkatan lebih signifikan daripada siswa di kelas kontrol. Hal tersebut dapat dilihatdari rata-rata ngain masing-masing kelas pada garfik berikut:

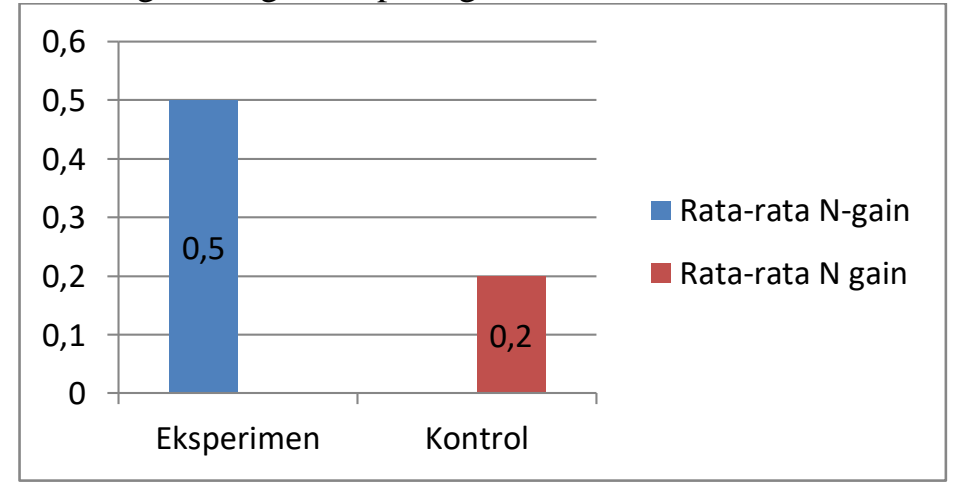

Grafik 3. Rata-rata N-gain keterampilan cross cultural siswa

Hasil pengolahan menggunkan statistik uji t $\mathrm{N}$-gain antara kelas eksperimen dan kelas kontrol adalah sebagai berikut.

Tabel 3. Hasil uji t Ngain kelas eksperimen dan kelas kontrol

\begin{tabular}{|c|c|c|c|}
\hline Uji t Ngain & Sig.(2-tailed) & Signifikansi & Keterangan \\
\hline Eksperimen & \multirow{2}{*}{$0,000: 2=\mathbf{0 , 0 0 0}$} & \multirow{2}{*}{0,05} & \\
\hline Kontrol & & & $\begin{array}{l}\text { perbedaan } \\
\text { Peningkatan }\end{array}$ \\
\hline
\end{tabular}

Berdasarkan hasil pengolahan data tersebut diperoleh sig.(2-tailed) 0,000 dibagi dua karena hipotesisnya satu arah sehingga diperoleh sig.(one-tailed) $0,000<0,05$ dapat diartikan bahwa kegiatan pembelajaran melalui penyusunan bahan ajar bebasis berbasis $v \log$ lebih memberikan dampak peningkatan yang lebih signifikan dibanding pembelajaran konvensional dalam meningkatkan keterampilan komunikasi mahasiswa PGSD pada mata kuliah magang IPS SD.

\section{Pembelajaran di Kelas Eksperimen}

Pembelajaran yang dilakukan di kelas eksperimen adalah pembuatan bahan ajar berbasis vlog untuk meningkatkan kemampuan komunikasi mahasiswa PGSD IKIP Siliwangi. Pembelajaran diterapkan pada mahasiswa semester 4 kelas A1 pada mata kuliah magang IPS SD. Pembelajaran dilakukan selama tiga kali pertemuan. Pada pertemuan pertama mahasiswa masih merasa canggung dalam melaksanakan pembelajaran IPS berbasis $v$ log dikarenakan tidak terbiasanya membuat video dan berbicara langsung untuk direkam yang bertujuan memberikan informasi dalam proses pembelajaran. selain itu ditemukan pula keunikan lain dalam proses pembelajaran berbasis $v$ log tersebut yaitu rasa percaya diri mahasiswa yang masih terlihat kaku dalam berkomunikasi dengan teman lainnya ketka membuat sebuah rekaman video. Temuan-temuan pada pertemuan pertama dianalisis dan diperbaiki untuk melanjutkan penelitian pada pertemuan kedua yaitu dengan cara membuat rencana pembelajaran yang lebih maskimal dengan menjelaskan langkah-langkah pembuatan vlog dalam memberikan informasi untuk proses pembelajaran. Dalam pembelajaran pertemuan 
kedua siswa dibagi menjadi ebebrapa kelompok dengan tujuan untuk memberikan kesempatan pada siswa saling bekerjasama dalam membuat video dan merancang topik pembicaraan dalam berkomunikasi membuat vlog tersebut. Perbaikan-perbaikan yang dilakukan pada pertemuan kedua memberikan perolehan hasil yang cukup baik dalam peningkatan keterampilan komunikasi mahasiswa melalui pembuatan bahan ajar berbasis $v \log$.

\section{Pembelajaran di kelas kontrol}

Pembelajaran di kelas kontrol yaitu kelas A2 mahasiswa PGSD IKIP Siliwangi semester 4 dilaksanakan tiga kali pertemuan menggunakan pembelajaran konvensional. Pembelajaran konvensional yang dimaksudkan adalah pembelaharan IPS dengan melakukan presentasi kelompok membahast opik materi IPS SD. Dalam proses pembelajaran pertama di kelas ini tidak terlalu banyak hambatan yang terjadi karena mahasiswa sudah terbiasa melakukan proses pembelajaran dengan presentasi kelompok. Akan tetapi ada hal-hal menarik yang ditemukan dalam proses pertemuan pertama yaitu pemaparan materi kelompok yang tidak terlalu jelas dalam penyampaian pada teman lainnya yang memperhatikan serta kurangnya antusias peserta kelompok lain dalam memperhatikan presentasi temannya di depan. Berdasarkan hasil wawancara langsung yang dilakukan hal ini terjadi karena mahasiswa mulai jenuh dengan proses pembelajaran dengan prsentasi kelompok, selain itu tampilan dan kesiapan kelompok yang tampil dianggap kurang menarik karena tidak terlalu memahami materi dan kurang menarik dalam penyampaian. Temuan-temuan yang didapat dalam pertemuan pertama diperbaiki baik itu dalam kesiapan materi dan pemahaman anggota kelompok, power point yang ditampilkan serta kemampuan menyampaikan informasi pada kegiatan presentasi untuk dilakukan di pertemuan kedua. Hasil perbaikan pada pembelajaran dipertemuan kedua menunjukan dampak yang positif terlihat adanya peningkatan keterampilan komunikasi mahasiswa dibandingkan dengan hasil pretest, namun masih tetap saja ada beberapa siswa yang tidak antusias dalam pelaksanaan pembelajaran dikarenakan mahasiswa tersebut merasa bosan dengan metode pembelajaran seperti itu. Berdasarkan hasil dan pembahasan pada peneilitian ini, diharapkan penelitian dapat memberikan impilaksi-implikasi seperti 1) pebelajaran berbasis vlog dapat meningkatkan keterampilan komunikasi mahasiswa dalam proses pembelajaran; 2) pembelajaran berbasis vlog dapat meningkatkan kemampuan mahasiswa PGSD dalam membuat bahan ajar yang mampu meningkatkan komunikasi siswa; 3) pembelajaran berbasis vlog dilakukan sesuai dengan perkembangan teknologi yang semakin hari semakin berkembang sehingga mengikuti perkembangan zaman; 4) dengan menerapkan pembelajaran berbasis Vlog rasa percaya diri mahasiswa dalam berkomunikasi semakin menimgkat dan tidak memberikan kebosanan dalam proses pembelajaran yang biasa dilakukan.

\section{KESIMPULAN}

Berdasarkan temuan dan hasil dari pene;itian yang dilaksanakan seperti yang telah dipaparkan sebelumnya simpulan penelitian ini adalah 1) pembelajaran dengan menerapkan bahan ajar bebrbasis vlog dapat meningkatkan keterampilan komunikasi mahasiswa PGSD IKIP Siliwangi dalam mata kuliah magang IPS SD; 2) pembelajaran berbasis vlog lebih baik dibandingkan pembelajaran konvensional; 3) pembelajaran berbasis vlog membutuhkan persiapan yang matang dalam perencanaan dan penyediaan media elektronik baik itu kamera, handycame maupun smart phone untuk digunakan dalam proses pembelajaran; 4) perlu adanya kreativitas yang tinggi ketika pelaksanaan pembelajaran berlangsung untuk menanggapi respon mahasiswa yang di luar prediksi seperti ketika membagi kelompok di kelas kontrol ternyata siswa terlihat tidak antusias dengan hasil pembagian kelompok.

\section{UCAPAN TERIMA KASIH}

Terima kasih kepada IKIP Siliwangi yang telah memberikan dana penelitian internal melalui lembaga penelitian dan pengabdian kepada masyarakat, memberikan dukungan dan arahan sehingga penelitian ini dapat berjalan dengan lancar.

\section{REFERENSI}

Arsanti, M. (2018). Pengembangan bahan ajar mata kuliah penulisan kreatif bermuatan nilai-nilai pendidikan karakter religius bagi mahasiswa prodi pbsi, FKIP, Unisulla. Jurnal Kredo Vol. 1 No. 2.

Chatab, N. (2007). Profil budaya organisasi. Bandung: Alfabeta.

David, Sondakh, dan Harilama. (2017). Pengaruh konten vlog dalam youtube terhadap pembentukan sikap mahasiswa ilmu komunikasi fakultas ilmu sosial dan po litik universitas sam ratulangi. e-journal Acta Diurna Volume VI. No. 1. 
Marfuah. (2017). Meningkatkan Keterampilan Komunikasi Peserta Didik melalui Model Pembelajaran Kooperatif Tipe Jigsaw. Jurnal Pendidikan Ilmu Sosial Volume 26, Nomor 2.

Mulyasa. (2006). Kurikulum tingkat satuan pendidikan. Bandung: Rosdakarya.

Priana, R. (2017). Pemanfaatan vlog sebagai media pembelajaran terintegrasi tekhnologi informasi. Prosiding Seminar Nasional Pendidikan FKIP UNTIRTA.

Septiyan, G. (2017). Pengaruh model teams games tournament terhadap keterampilan pengambilan keputusan dalam pembelajaran ips di sekolah dasar. Mimbar Sekolah Dasar, 4(1), 106-116. doi:http://dx.doi.org/10.23819/mimbar-sd.v4i1.5547 